\title{
Balkan Candidate Countries Running for Fiscal Consolidation: Legal Frameworks vs. Economic Results
}

\author{
Aleksandra Maksimovska Stojkova \\ Full-time Professor, Ss. Cyril and Methodius University, Department of Financial \\ Law, lustinianus Primus Faculty of Law, Skopje, Republic of Macedonia \\ e-mail: a.maksimovska@pf.ukim.edu.mk
}

\author{
Elena Nesovska Kjoseva \\ Assistant Professor, Ss. Cyril and Methodius University, Department of Financial \\ Law, lustinianus Primus Faculty of Law, Skopje, Republic of Macedonia \\ e-mail: e.neshovska@pf.ukim.edu.mk
}

Irena Stojmenovska

Assistant Professor, American College, UACS, Skopje, Republic of Macedonia e-mail: irena.stojmenovska@uacs.edu.mk

\section{Abstract}

The subject of this paper is four Balkan countries (Albania, Serbia, Macedonia, and Montenegro) that are determined to join the European Union. More particularly, it looks at their work towards accomplishing the political, legal and economic requirements for the EU. Thus, the legislation with the EU Fiscal Compact is the prime focus. Methodologically, the research is based on an assessment of fiscal and monetary legal documents, evaluating the stages of accomplishing the harmonization with the EU's conditions. Further, cross-section analyses are made by in putting selected indicators; additionally, the authors compare the four countries' achievements. The EU's rigorous fiscal rules are being quietly bypassed, but more frequently by existing member states than the candidate states; this statement is founded on legal and economic arguments, with mathematical estimations. Consequently, the authors question the political courage and financial capacity of the examined countries to cope with the fiscal compact of the superior EU 28 members. The answers are supported with numerous analyses of EU Reports for each country, as well as tables and figures that compare the states' results and economic achievements vs. EU fiscal consolidation rules. The 
EU 28 average is givenin addition as a comparison. The conclusion gives across analysis between the four countries and the EU 28 member states, with accompanying argumentation to the main statement about the legal and economic developments of the examined Balkan countries as well as a future prognosis.

Keywords: EU Fiscal Compact, fiscal consolidation, budget deficit, public debt, Balkan candidates

JEL: H3, H6, H62, H63

\section{Introduction}

Working hard on EU Harmonization has been a strategic decision for the Balkan countries in the past decade. The main focus has been put on coping with the European Union's legislation. In addition, other accession requirements have been asked. Those are primarily from a fiscal and monetary perspective, where these Balkan countries are supposed to fulfill the following requirements: (1) to stabilize their public finances in general; and (2) to ensure budgetary discipline and fiscal consolidation. At the same time, the EU member states have the same rigorous fiscal and monetary rules to follow, imposed by the Maastricht Treaty and the Stability and Growth Pact (mostly in the Fiscal Compact). This is a paradox, because the member states are already in a better fiscal and budgetary condition, supported by numerous EU Budget funds. The Fiscal Compact contains provisions that harden member states' commitment to budget discipline and creates mechanisms to ensure compliance with the ones that exist under EU legislation.

In the last few years, the pro-EU orientations of the Balkan governments resulted in them mostly accepting budget balance rules and the debt rule as a symbol of determination for their future European integration. The result is that, while more developed and economically powerful authoritative EU states still complain about the rigorous EU fiscal burdens, the candidate countries with developing economies and unsound public policies are supposed to take greater steps and proceed with the EU requirements. The question that arises is whether the candidate countries should be brave and politically strong enough to cope with the Fiscal Compact, or to copy the less desirable EU member state's behavior, avoiding and neglecting the rules. There are several alternatives. If they follow the EU fiscal rules as strictly as are set by the Treaty, the result will be that Balkan candidates will have more exact legislative solutions than the EU member states. Alternatively, if they soften or slightly avoid some of the rigorous implementation rules, as many of the member countries do, they will be closer to the grey-zone practice of the other states. The truth is that the rigorous EU fiscal rules are being quietly bypassed, but more frequently by the member states than by the candidate countries.

The main question in this paper is whether these four candidates should follow the rules strictly and firmly stick to the EU fiscal agenda, or if they could loosen up a bit, 
in order to avoid some additional pressure on their national fiscal policies, and to fix other burning national financial questions, until they finally join the Union. The answer would have both political and financial angles. Here we are going to investigate the implemented financial features of the EU rules by four EU candidates from the Balkans (Albania, Macedonia, Montenegro, and Serbia). The following concerns are going to be examined next: the need for fiscal and monetary rules in the monetary union; the importance of the Fiscal Compact for both the EU members and candidates; the struggle of the four EU candidates during the process of accomplishing various pre-conditions and following rigorous rules; the challenges that are faced while completing the different tasks, first in implementing the legislation and second when working out practical problems. Methodologically, the legal inquiry will be take up the major part of the paper, and the fiscal consolidation legal framework will be used to compare the four candidates in a separate portion, accompanied by mathematical calculations. A conclusion with de lege ferenda actions and recommendations for the EU candidates will follow.

\section{Rules on the public finances in the Eurozone}

\section{The need for fiscal rules in a monetary union}

The European Union is the most desired union for membership, and therefore under pressure for new memberships, but monetary and fiscal difficulties, such as a constant budget deficit and increasing public debt, harm the process of enlargement and regular functioning. There was significant stagnation in GDP among most of the member states as a result of the financial crises in 2007. As monetary and fiscal policy are always correlated and presented as two sides of one coin, there was a need for mutual coordination in the European Union. The EU, seeking solutions, established a set of supranational monetary rules and coordinated national fiscal policies.

The EU monetary policy is based on a common currency in the eurozone, governed on a supranational level by an independent EU central bank. On the other side of the coin, the fiscal policy encompasses mutual and harmonized fiscal activities of the national governments. Therefore, it is understandable that the will to establish a stable monetary union with solid monetary policy has driven constant pressures to implement sound fiscal rules in the last decade. Therefore, stronger coordination of fiscal policies between EU member states is needed.

If fiscal policies were not coordinated, it might endanger the functioning of the monetary policy and cause a crack in the monetary union. In order to avoid unbalances in the monetary policy, a common set of budgetary and debt rules are set by the Maastricht Treaty. It is recommended that the rules be followed, and avoiding them will result in various monetary difficulties, which was undoubtedly confirmed by the 
financial crisis in the last decade in Greece, Spain, Italy, and Portugal. Actually, the global financial crisis that began in late 2007 prompted a revision of financial services regulation in the EU. From 2010 onwards, the banking crisis was followed by the sovereign debt crisis in the euro area, which, among other consequences, increased the fragmentation of the single financial market. For example, the increased sovereign risk in the Greek bonds increased the interest rates for borrowing for Italy, Spain and other countries that were facing problems in their public finances.

Furthermore, the high level of dependence of the EU states' financial markets can cause distortions among the holders of financial instruments. In this case, a distortion in a member state's financial market can easily be exported in the eurozone. Yet again, the financial crisis showed that in the EU, the German and French investors were exposed to the Greek and Cypriot sovereign debt bond and it put the stability of the French and German banks in danger (Maksimovska et al. 2018). Consequently, the overall stability of the financial markets in these countries was put into question.

Additionally, the problem of monetary liquidity in the EU rises. As an example, in time, a member state faces monetary liquidity difficulties, so the EU central bank pressures the national central bank to undertake specific measures to resolve the liquidity. Since the markets are integrated and other member states do not face the same liquidity problems, such a request might produce inflation and other negatively correlated complications. The establishment of the European Banking Union was an attempt to address the increasing fragmentation of financial markets in the EU.

In the area of the single currency, fully aware of the potential correlated financial implications of the mutual monetary policy, the creators of the EU treaties asked for broad coordination of the fiscal policies among EU member states. The founding treaties contain numerous restricting rules to limit the nation states' fiscal policies (Bickerton et al. 2015). Since the EU faces different challenges, the process of upgrading those fiscal rules is ongoing, and as a result, we have budget balance and debt rules empowered in the Fiscal Compact.

\section{The Fiscal Compact- the Stabilization Key for Public Debt and Budget Deficit}

The Fiscal Compact is a step towards a true "fiscal stability union", as it aims to strengthen the fiscal governance framework in the euro area and it addresses some of the shortcomings of the Stability and Growth Pact (SGP). It provides the framework that coordinates member states' fiscal policies and ensures fiscal sustainability while encouraging economic growth. The SGP was originally built on three principles: the requirement for member states' budgets to be close to balance or in surplus in the medium term; a ceiling of 3\% of GDP for the overall fiscal deficit; and a ceiling of $60 \%$ of GDP for public debt. Before the sovereign debt crisis, the SGP had already been revised (2005), following the political debacle associated with the breach of the deficit ceiling by France and Germany (Burret et al. 2013). In particular, the 2005 reform increased the flexibility 
of the fiscal rules by introducing the notion of country-specific medium-term budgetary objectives (MTO). In 2011, the adoption of the "Six Pack' legislation further revised the operation of the SGP (European Commission 2011).

The Treaty stipulates that a government's annual budgetary position shall be balanced or in surplus, a provision also known as the golden rule. Specifically, Member States commit to not having a structural deficit higher than $0.5 \%$ of GDP. This commitment differs from those under the SGP, where the lower limit to the structural deficit is $1 \%$. Second, the Treaty strengthens the correction mechanisms in case of slippages from the structural balance budget rule. In particular, translation of the balance budget rule into national law must be done in a binding and permanent way, preferably at the constitutional level, and must be monitored by an independent supervisory institution, such as a fiscal council.

The EU members demonstrate various actions of resistance towards the implementation of fiscal rules, and the numerous reports and acts are in order to support and evaluate these activities (EU Commission 2017).Consequently, the members need more assistance for coordination and guidance of the public finances. All members should be aware that their fiscal and monetary obligations as members are the same for the candidates as perquisites for entrance into the EU. However, recently, at the end of 2018, The Italian Budget Proposal was programmed with public debt of $130 \%$ of GDP, which is a direct harm to the EU's fiscal rules. The Commission promptly suggested a correction of the proposal, and Italian budget policy, but the Italian Prime minister put his foot down in supporting the Budget proposal, arguing that it is a necessity. As the situation expands, the EU's executive arm, the Commission, is threatening to launch disciplinary measures. The main problem is that Italy's 2019 Budget Proposal does not comply with the EU's requirement that member states work to reduce their debt piles. As such, the Commission will now launch what is known as an "Excessive Deficit Procedure" that could lead to Italy being fined (CNBS, November 2018).

\section{Fiscal Turbulences in Balkan Countries}

The necessary amendment of the Monetary Union through the fiscal rules requires European-shaped national economic and financial budgetary policies. In the multi-level constitutionalism of the European Union, this implies that the national competencies will remain, but need to be vastly better interlocked with European guidelines, combined with more effective monitoring and surveillance resulting from this (Calliess 2012).

At this moment, the high level of public debt and stagnating economic growth make the four Balkan countries' position under the EU fiscal rules, at best, problematic. To comply with these so-called external constraints, as an obligation under the process of accession, they are required to continuously lower their public debt year after year. In the next 
section, we present four different legal frameworks and analyze: (1) the degree of harmonization with the EU's fiscal consolidation framework and; (2) specific states' variations regarding public debt and budget deficit regulations. The goal is to detect whether the harmonization of legislationis positively correlated with resolving the public debt and budget deficit issues. In other words, is the harmonization just cosmetic for faster EU integration? This brings the general dilemma of the efficiency of EU fiscal rules into question.

\section{Coping with the EU rules: harmonization of the legal framework}

The duality in coping with the EU rules is based on: (1) the fact that there is a general obligation for the country to harmonize its legislation with the EU's acquis communautaire; (2) introducing the euro. These goals require actions relating to the budget deficit and public debt, as part of the treaties and protocols which are primary inevitable in EU harmonization. Since no opt-out clauses might be granted for the new members of the EU, the process of preparing for the adoption of the euro as a national currency should start even in the pre-accession period (ECB 2000).

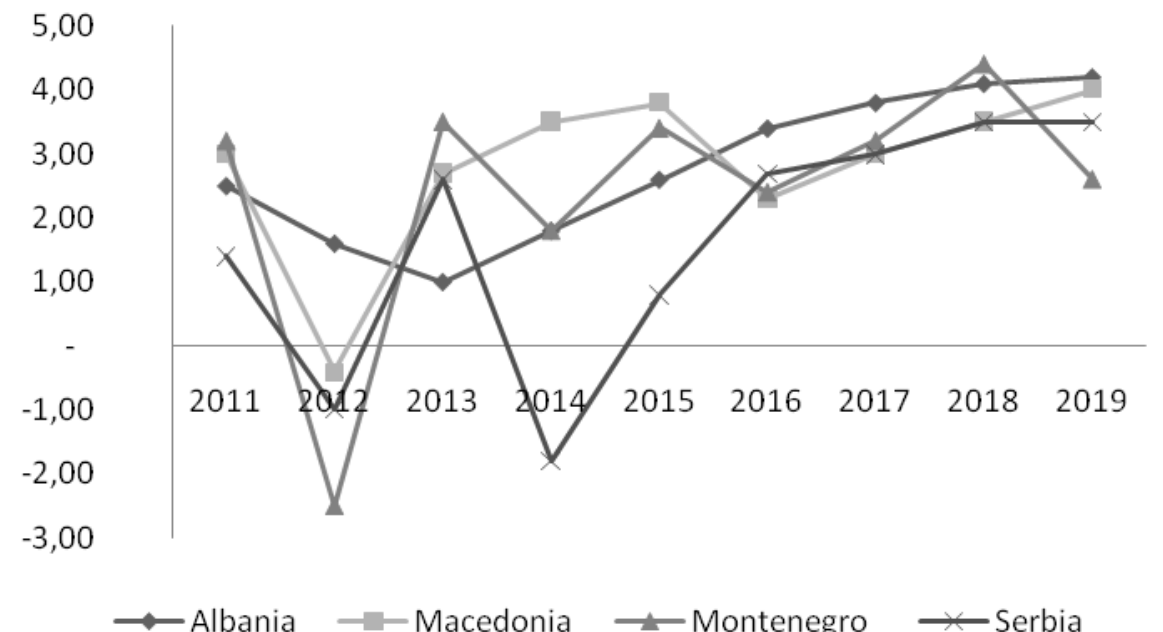

Chart 1. Real GDP growth (\% of change): year 2011-2019

Source: European Commission, 2018 Economic Reform Programmes of Albania, FYR Macedonia, Montenegro, Serbia, Turkey, Bosnia and Herzegovina, and Kosovo.

The following chart shows the trends in public finances in the initial period of establishing fiscal rules (Fiscal Compact in 2011) through the years of implementation, up to today, and with forecasting for the next two years, until 2019, according to the MTO.

As can be seen from the trends in Chart1, all four candidate countries faced decreased GDP in 2012 as an additional negative pressure at the time of accepting the strict fiscal rules. Afterward, the lines mark an increasing trend in 2014-2016. In that period, the single market economy was healing, which obviously had a positive impact 
on the Balkans economies. This process is ongoing with a positive trend and makes an additional "pro" argument in the country's progress reports. It is undoubtedly not an easy process to cope with the rigorous EU rules, while other members are avoiding the same ones.

\title{
The Legal Outlook of the Fiscal Rules
}

\begin{abstract}
Albania
Albania has just introduced a fiscal rule regarding the limitation on public debt in the Budget System Management Law (no. 9936/2008). In the first years of operation, the Law insisted on restricting total public debt while the guarantees must not exceed $60 \%$ of GDP (Article 58).Until there was a programme between Albania and the IMF (2009), the macroeconomic activities tended to be quite prudent (World Bank 2015). When the programme expired, a significant portion of disciplining pressures on Albanian fiscal policy was out of action. Influenced by the consequences of the 2008 financial crises and domestic political pressures, the GDP dropped to a level substantially lower than projected, while the deficit and the debt ratio shot up (Jonas 2010). At the end of 2012, the legally binding ceiling on the debt ratio of 60 percent was removed by a simple majority vote in the Parliament, without replacing it with any other fiscal or debt anchor. This legal "damage" destabilized public finances, turning Albania backward (Klepsvik et al. 2014).

In order to ensure fiscal discipline and improve the fiscal framework, in 2016, the Albanian Parliament amended the Organic Budget Law and readopted the fiscal rule (Durmishi et al. 2016). This time, the difference was in the secured political support by the majority in the Parliament as a solid base for all future Albanian governments (Ministry of Finance of Albania 2017). In essence, the rule is to reduce and keep the public debt level towards 45\% of GDP. Evidently, it is 15\% less than the EU fiscal consolidation rule, aiming to build more buffers for slowdown periods. Another important provision is the inclusion of a contingency fund of at least $0.7 \%$ of total budget expenditures in the annual budget. Finally, the amendments to the Organic Budget Law require the Ministry of Finance to be more responsible and transparent by giving reports to a wider number of the state's official institutions. Besides these strict and rigorous limitations, some shortcomings are present, which means that the legislators did not set a time deadline for these goals and did not introduce an independent monitoring body to control the compliance of the amendments. As a substitute, one fiscal unit at the Ministry of Finance became fully operational for monitoring and reporting on fiscal risks. However, this body cannot guarantee its independence, and therefore the legal changes only partially follow the EU's fiscal requirements.
\end{abstract}




\section{Macedonia}

Preparations for the introduction of the fiscal rule, originally planned for January 2017, are on hold. The reason lies in the political crisis and the absence of a two-thirds parliamentary majority required to amend the Constitution. The fiscal rules were ready to be introduced in the Macedonian Constitution while the law enforcement would have been most efficient.

The rules (on the waiting list) limit the general government fiscal deficit to $3 \%$ and the public debt level to $60 \%$ of GDP, as prescribed by the EU. The Government could go beyond these limits only in exceptional situations, such as natural disasters and external shocks that are a threat to national security, human health and which result in a significant decline in real GDP. The Assembly will be in charge to confirm such situations, with a two-thirds majority, which indicates broader political support for the Government (Zafiroski 2014). The legal framework includes an independent monitoring and oversight body, as well as other enforcement mechanisms (Hristovska et al. 2017). Even though it is expected that the legislation will be introduced shortly, the Macedonian government has not defined measures yet to execute the fiscal consolidation plans.

As the country has received a promising Report from the Commission and additionally a possible date to start pre-accession negotiations, due in June 2019 (as a result of Constitutional Amendments made recently), the situation is seen as vastly improved. However, the chapter of the Constitutional provisions regarding EU rules for fiscal consolidation is still on the waiting list. In the meantime, the country is moving towards the latest (2017) EU Report recommendations, and the current state of public debt and budget deficit is satisfactory (European Commission 2017).

A satisfactory note is that public debt is far lower than the restrictive EU fiscal rules demand. Specifically, public debt towards GDP has been between 35-40\% over the past five years. It turns out that Macedonia, with no fiscal limitations in the legislation, has gained better results than the average of the EU 28 states in practice.

\section{Montenegro}

The legislative analysis shows that Montenegro does not have a lex specialis for public debt regulation, but state borrowing provisions are found in the Law on Budget and Fiscal Responsibility. Fiscal responsibility legislation limiting the cash deficit and public debt of the General Government was adopted in 2014 in line with the Maastricht limits. According to the Law on Budget and Fiscal Responsibility (Official Gazette of Montenegro, No. 2014 and 56/2014), article 20, paragraph 1, there are two major rules for fiscal consolidation: First, the level of the budget cash deficit of the General Government should not exceed the level of 3\% of GDP at market prices. If the deficit deviates from the limit, a formal procedure requires the government to outline the measures within 60 days of the moment of the deviation, in order to bring the deficit back to the prescribed level. Second, the level of the public debt should not exceed the level of $60 \%$ of GDP at market prices. If the debt reaches 60 percent of GDP, the Gov- 
ernment has to propose amendments to the State Budget Law to bring the debt to the given level. When the debt exceeds 60 percent of GDP, the Government has to propose to Parliament a reduction of multi-year expenditures, a reduction of municipal expenditures, as well as supplementary actions to ensure a reduction of State debt. The next situation is if the debt exceeds 60 percent due to capital projects (where Parliament has decided the borrowing), the Government has to propose a debt reduction program for a period not exceeding five years. During the fiscal year, if there is a lower outturn of revenues, the Montenegran Government is obliged to define the fiscal policy measures to ensure the recovery of the stated budget cash deficit as stated in the Law on fiscal restrictions.

From recent practice, the legal provisions were violated in 2015 and 2016, when the fiscal limitations were disrespected. The Government, as stated in the Law, was obliged to take action, but its plan for debt reduction was postponed for political reasons, until the elections in October 2016 (European Commission 2016). As a result, the Government has not managed to be fully consistent with the legislative and strategic framework for managing public debt. The conclusion is that even though fiscal consolidation rules have been introduced, political pressures have a negative impact and slow the enforcement of the law (Calovic Markovic et al. 2017).

\section{Serbia}

As a result of fiscal turbulences, the Government in Serbia has adopted a package of measures to stabilize public finances and economic recovery (Djurovic-Todorovic et al. 2015). In October 2010, fiscal responsibility law provisions were introduced in the Budget System Law. The most characteristic difference from the other analyzed countries is in the numerical quotations, where fiscal rules limit the public debt-to-GDP ratio to $45 \%$. Additionally, another specific is the establishment of the Fiscal Council, aimed at scrutinizing the government's fiscal performance (Kalas et al. 2016). In short, the fiscal rules state:

Budget Balance Rule: The maximum fiscal deficit-to-GDP ratio in year $t$ is calculated as $\mathrm{d}(\mathrm{t})=\mathrm{d}(\mathrm{t}-1)-0.3\left[\mathrm{~d}(\mathrm{t}-1)-\mathrm{d}^{*}\right]-0.4\left[\mathrm{~g}(\mathrm{t})-\mathrm{g}^{*}\right]$ where $\mathrm{d}^{*}$ is the medium-term deficit which is set at 1 percent of GDP, $g$ is the real GDP growth rate, and $g^{\star}$ is the medium-term GDP growth (set at 4 percent). Thus, the rule corrects for past deficit deviations and allows the partial operation of automatic fiscal stabilizers. Over the medium-term the targeted annual deficit will be $1 \%$ of GDP.

Debt Rule: General government debt, excluding the liabilities arising from the restitution, cannot exceed $45 \%$ of GDP.

The Fiscal Council is an independent legal entity, accountable to the National Assembly, responsible for assessing the credibility of the fiscal policy in terms of compliance with established fiscal rules.

Under exceptional circumstances (natural disasters and external shocks, national safety, a drop in economic activities) and only for a limited period, the Government may deviate from the fiscal principles and rules specified by this Law. 
So far, the Law has been amended nine times, as a vivid example of the time consistency problem, and most of the changes included wage and pension increases. However, the key rules on debt and deficit were not amended but were avoided repeatedly each year. The problem seems to be in the inefficiency of the National Assembly if its powers are set just by one legal act. Constitutional changes may be more effective, as suggested by the academia in Serbia.

\section{Evaluation of the Economic Determinants}

\section{Methodology for assessment}

Since fulfillment the Maastricht limitations is recognized as an important dimension for EU accession, and also for good public finance management, the next academic exercise is empirical mapping by specific indicators. This methodology is employed to address the central question of whether the four selected states sufficiently follow the EU's fiscal rules. We have built four indicators that came from the Fiscal Compact requirements: (1) The budget balance rule (35\% impact), (2) The debt rule (35\% impact), (3) The independent fiscal body (20\% impact), and (4) Well-defined escape clauses (10\% impact).

All the indicators have been extensively elaborated in the previous sections of the paper, and therefore, here we prescribe the exact percentage points. The composition of the newly designed values of the indicators is appropriate for countries that embarked on EU integration in the last decade. For example, our methodology would be more applicable to the region of South Eastern Europe than to EU state members. Also, the methodology is linked with a special emphasis on the former group of developing and transition regions and countries, under the umbrella of the term "consolidating democracies'. Additionally, the methodology reflects the policy actions and policy implications of fiscal consolidation. Due to the prescribed percentage points, it was designed and discussed with numerous experts (faculty colleagues). For example, the first two indicators have significantly more percentage points of weight in the total points, because the budget balance rule and the debt rule play a much more important role in the process of disciplining the states to follow the EU fiscal rules.

On the other hand, the other two indicators were assigned $20 \%$ and $10 \%$, due to their lower importance role in the process. Although the states are still outside the EU, they are strongly committed to the idea of keeping good fiscal discipline. Consequently, all the analyzed countries (Macedonia is going to adopt them in the very near future) are more willing to apply the first two Fiscal Compact requirements; although they will pose limitations on their national policies, the final result will be drastically improved and sounder fiscal stability. In the case of the other two indicators, the legal analysis showed that the states are not ready to cope with the EU's fiscal standards yet; however, hopefully, they will foster some additional arrangements in fulfilling these criteria in the near future. 
Table 1. Assessment of the indicators for fulfilling the Maastricht limitations

\begin{tabular}{|l|c|c|c|c|c|}
\cline { 2 - 6 } \multicolumn{1}{c|}{} & $\begin{array}{c}\text { Budget } \\
\text { balance } \\
\text { rule } \\
(35 \%)\end{array}$ & $\begin{array}{c}\text { Debt } \\
\text { rule } \\
(35 \%)\end{array}$ & $\begin{array}{c}\text { Independent } \\
\text { body (20\%) }\end{array}$ & $\begin{array}{c}\text { Well specified escape } \\
\text { clauses (10\%) }\end{array}$ & $\begin{array}{c}\text { Overall score } \\
\text { (max 100\%) }\end{array}$ \\
\hline Albania & $0 \%$ & $35 \%$ & $0 \%$ & $0 \%$ & $35 \%$ \\
\hline Macedonia & $0 \%$ & $0 \%$ & $0 \%$ & $10 \%$ & $80 \%$ \\
\hline Montenegro & $35 \%$ & $35 \%$ & $0 \%$ & $10 \%$ & $100 \%$ \\
\hline Serbia & $35 \%$ & $35 \%$ & $20 \%$ & $0 \%$ & 0 \\
\hline
\end{tabular}

Source: author's assessment based on own calculations vis-à-vis legal framework analyses.

\section{Assessment Results}

The results are clear and reflect the legislative framework in the four selected countries. Serbia, as the winner and holder of $100 \%$ of the total points, has been leading in the process of fulfilling the requirements. Montenegro, althoughit has insisted on fostering the process of coping with the EU Fiscal Compact, has dropped the rule for the establishment of an independent fiscal body. Albania gained just 35\% of the total $100 \%$, because the legislator did not manage to persuade the parliament majority to adopt all of the EU fiscal rules. In the case of Macedonia, there is nothing in exact legislative acts to deal with the EU's fiscal rules (de lege), but, as it is expected that the Macedonian Parliament will adopt and implement all four fiscal requirements as soon as possible, there is quite a solid base from which the improvements can be accomplished.

\section{Public finances vis-à-vis practical numbers}

According to Eurostat, Macedonia has the lowest budget deficit and general government debt. This is in stark contrast with the current legislative solutions and means that Macedonia has not accepted the Constitutional amendments (due to changes in the Parliamentary majority and in the government). However, in practice, the numbers show the significant superiority of Macedonian public finances compared to the other three analyzed countries. Additionally, it has to be underlined that the state of public finances (budget deficit and public debt) is in much better shape than the EU 28 average. The reason for such interesting numbers is that in 2014, the Macedonian government paid off a huge amount of public debt and improved the image and starting position for new public borrowing that has occurred recently. Serbia and Albania share similar trends in public finances, but Montenegro is far behind the average (see Charts 2 and 3). 
Aleksandra Maksimovska Stojkova, Elena Nesovska Kjoseva, Irena Stojmenovska

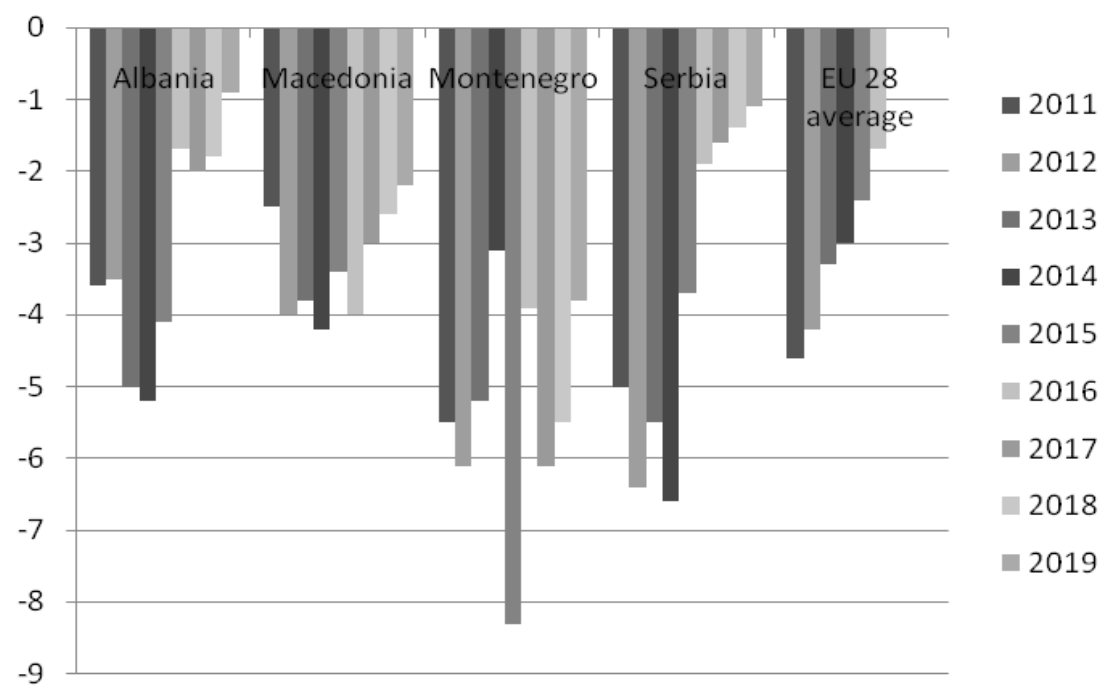

Chart 2. General government balance (\% of GDP)

Source: European Commission, 2018 Economic Reform Programmes of Albania, FYR Macedonia, Montenegro, Serbia, Turkey, Bosnia and Herzegovina, and Kosovo.

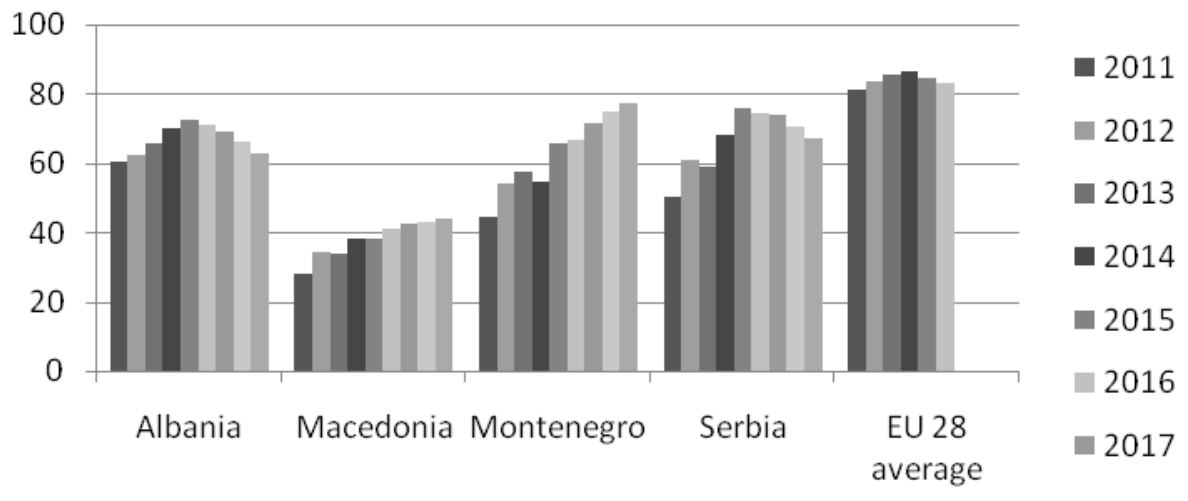

Chart 3. General government debt (\% of GDP)

Source: European Commission, 2018 Economic Reform Programmes of Albania, FYR Macedonia, Montenegro, Serbia, Turkey, Bosnia and Herzegovina, and Kosovo. 


\section{Legislative analyses versus practical numbers: "Black and White Contrast Results"}

In the following tables (2, 3 and 4$)$, we evaluate the four states on the basis of cross-section analyses. It is an assessment of the real state of public finances in the four selected countries, but taken as an amalgamation of the legislative assessment given in Table 1 and the practical assessment presented in Charts 2 and 3.

The numbers demonstrate a specific country, for example Serbia, is evaluated better for the legislative, compared to the financial situation, vs. Macedonia, that stands better regarding finances, compared to evaluated legislation. In the same example, the discrepancy in the Macedonia's results, where this country has 0 points according to the fulfillment of the EU's Fiscal Compact rules, is in contrast with the current numbers of the public debt and budget deficit. On the other hand, there is another example that supports the thesis "Black and White Contrast Results" in the case of Montenegro. Here the legislative framework is in quite a good shape according to the EU's Fiscal Compact, but the state in public finances is discouraging.

Table 2. "Budget balance rule -BBR" grade

\begin{tabular}{|l|l|}
\hline $\mathrm{BD}<\mathrm{bbr}$ & 5 \\
\hline $\mathrm{BD}>$ bbr for 0.5\% & 4 \\
\hline $\mathrm{BD}>$ bbr for $1 \%$ & 3 \\
\hline $\mathrm{BD}>$ bbr for $2 \%$ & 2 \\
\hline $\mathrm{BD}>$ bbr for $2.5 \%$ & 1 \\
\hline No rule in legislation & 0 \\
\hline
\end{tabular}

*budget deficit - BD

Source: author's assessment based on own calculations vis-à-vis legal framework analyses and practical numbers.

Table 3. "Debt rule-DR" grade

\begin{tabular}{|l|l|}
\hline$G D<d r$ & 5 \\
\hline$G D>d r$ for $1-10 \%$ & 4 \\
\hline$G D>d r$ for $10-15 \%$ & 3 \\
\hline$G D>d r$ for $15-20 \%$ & 2 \\
\hline$G D>d r$ for $20-25 \%$ & 1 \\
\hline No rule in legislation & 0 \\
\hline
\end{tabular}

*government deficit - GD

Source: author's assessment based on own calculations vis-à-vis legal framework analyses and practical numbers. 
Table 4. Overall country's fiscal consolidation score

\begin{tabular}{|l|c|c|c|c|c|}
\hline & $\begin{array}{c}\text { Average } \\
\text { budget } \\
\text { deficit (\% } \\
\text { of GDP) }\end{array}$ & $\begin{array}{c}\text { BBR } \\
\text { Grade }\end{array}$ & $\begin{array}{c}\text { Average } \\
\text { General } \\
\text { Government } \\
\text { debt (\% } \\
\text { of GDP) }\end{array}$ & DB grade & $\begin{array}{c}\text { Overall fiscal consolidation } \\
\text { country score (taken } \\
\text { as average score- BBR } \\
\text { grade + DB grade /2) }\end{array}$ \\
\hline Albania & $-3,08889$ & 0 & 66,68889 & 1 & 0.5 \\
\hline Macedonia & $-3,3$ & 4 & 38,14444 & 5 & 4.5 \\
\hline Montenegro & $-5,27778$ & 2 & 63,01111 & 4 & 3 \\
\hline Serbia & $-3,68889$ & 1 & 66,72222 & 1 & 1 \\
\hline
\end{tabular}

Source: author's assessment based on own calculations vis-à-vis legal framework analyses and practical numbers.

\section{ASSESSMENT-BASED REMARKS AND PROGNOSIS}

Based on legislative provisions, EU Commission reports, practical issues, and an assessment of the conditions of the four selected Balkan countries, we conclude that:

- While more developed and economically powerful authoritative EU states still complain about the rigorous EU fiscal burdens, candidate countries with developing economies and unsound public policies are supposed to take greater steps and continue following the EU requirements. Here, the most recent case of Italy strongly supports this argument. Also, the analyses confirm that in the case of Albania, Macedonia, Montenegro, and Serbia, as candidate countries, it is clear that they are fully coping with the EU requirements. There is an ambitious determination to fulfill the rigorous requirements and be admitted, despite the heavy burden they carry, bearing in mind their current economic conditions; however, national priorities take precedence over problems in public finances, in this case.

- The candidate countries often make exhausting runs, where they put enormous work in order to achieve points and to cope with EU's rules. On the other hand, it is clear that they did not follow the example of some EU member states' behavior, in avoiding and ignoring the rules (for example, Italy). According to the cross-section evaluation (given in section 4.4.), there are various pathways to improve the country's progress and to cope with EU's fiscal rules, even among these four countries.

- The Macedonian case study confirms that it was not the case of wrong calculations or predictions, but a matter of a political problem that slowed the process slightly. However, a change will be made very soon in order to meet the EU's fiscal rules. Surprisingly the numbers in practice are closer to the EU 28 average. In the case of Montenegro, we can see how the state authorities followed all EU's fiscal requirements, but, the results in practise were not satisfactory. This two 
cases, twist around the argumentation that Balkan countries are not fiscally and legally prepared to be compared with EU member states.

- It is clear that the Balkan candidate countries are more than willing to deal with the EU's Fiscal Compact rules, given the promising economic, political, and other advantages that EU membership holds for its members.

Pro future we expect that:

- Montenegro will overcome the current public debt crises;

- Serbia will stop cutting own excellent legislative fiscal solutions, and will not avoid good EU Commission's recommendations;

- Albania will implement EU's fiscal rules and improve the evaluation grades that put her below the average of the Balkan countries; and

- Macedonia will adopt the drafted fiscal consolidation framework and continue working on sounder budget policy.

In practical sense, the assessment confirms that aspiration for EU membership made these four countries to implement the EU's fiscal rules more strictly than the current EU members, and additionally they should be seen in a more respectful manner, due to their financial results. In sum, the Balkan's consolidating economies showed significant prosperity in the last ten years.

\section{References}

Bickerton, J., Hodson, D., Puetter, U. (2015), The New Intergovernmentalism: States and Supranational Actors in the Post-Maastricht Era, Chapter 7, Oxford University Press, Oxford.

Burret, T., Schnellenbach, J. (2013), Implementation of the Fiscal Compact in the Euro Area Member States, German Council of Economic Experts, Working Paper 08/2013.

Calliess, C. (2012), From Fiscal Compact to Fiscal Union? New Rules for the Eurozone, Cambridge Yearbook of European Legal Studies, Vol. 14.

Calovic Markovic, V., Maras, V., Maskovic, A. (2017), Montenegro Public Debt Analyses, Balkan Monitoring Public Finances.

Djurovic-Todorovic, J., Djordjevic, M. (2015), Results of Fiscal Consolidation in Republic of Serbia, Procedia Economics and Finance 19.

Durmishi, A., Patonov, N. (2016), Albania's Fiscal Governance: A Good Example in EU Perspective, "Journal of International Relations", Faculty of International Relations, University of Economics in Bratislava, Volume XIV, Issue 2.

ECB (2000), The Eurosystem and the EU enlargement process, ECB Monthly Bulletin. European Commission, 2016 Macedonia Report, COM 2016.

European Commission, Communication from the Commission, The Fiscal Compact: Taking Stock, Brussels, 22.2.2017 C(2017) 1200 final.

European Commission, Montenegro 2016 Report, COM 2016.

European Commission, Report from the Commission presented under Article 8 of the Treaty on Stability, Coordination and Governance in the Economic and Monetary Union, 22.2.2017, C(2017) 1201 final. 
Hristovska, B., Spasova, T. (2017), Analyses of Public Debt in Republic of Macedonia, Balkan Monitoring Public Finances.

Jonas, J. (2010), Fiscal Objectives in the Post IMF Program World: The Case of Albania, IMF Working Paper WP/10/77.

Kalas, B., Andrasic, J., Pjanic, M. (2016), Aspects of Fiscal Consolidation: Evidence from Serbia, The European Journal of Applied Economics, 13 (2).

Klepsvik, K., Emery, R., Finn, B., Bernhard, R. (2014), Budgeting in Albania, OECD Journal on Budgeting, OECD Publishing, Vol. 2013/2.

Maksimovska Stojkova, A., Zafiroski, J., Neshovska Kjoseva, E. (2018), Coping with the EU Fiscal Compact: Cross Section Analysis of the Legal Framework and Economic Results by the Candidate Balkan Countries, JOR: Jahrbuch fur Ostreht, Band 59, ISSN 0075-2746, Verlag C.H. Beck, IOR Munchen.

Ministry of Finance of Albania (2017), Public Financial Management Strategy 20142020: 2016 Monitoring Report, Government of Albania.

Treaty on European Union, Official Journal C 191, 29.7.1992.

Treaty on Stability, Coordination, and Governance in the Economic and Monetary Union, agreed at the EU summit of 30 January 2012, signed on 2 March by the Heads of State or Government of all EU countries, with the exception of the United Kingdom and the Czech Republic.

World Bank Group Partnership (2015), Albania - Program Snapshot, 2015, World Bank.

Zafiroski, J. (2014), The Need for Fiscal Rules in the Constitution of the Republic of Macedonia, Pravnik, No. 271.

\section{Streszczenie}

\section{Bałkanskie państwa kandydujące na drodze do konsolidacji fiskalnej: uwarunkowania prawne a wyniki ekonomiczne}

W artykule poddano analizie cztery państwa bałkańskie (Albanię, Serbię, Macedonię i Czarnogórę), zdeterminowane by przystąpić do Unii Europejskiej. W szczególności jest on poświęcony analizie ich wysiłów służących spełnieniu politycznych, prawnych i gospodarczych warunków wejścia do UE. W związku z tym głównym punktem zainteresowania autorów było prawodawstwo dotyczące unijnego paktu fiskalnego. Od strony metodologicznej badania opierały się na ocenie dokumentów prawnych, regulujących kwestie podatkowe i monetarne. Dokonano oceny kolejnych etapów ich harmonizacji z regulacjami UE. Ponadto wykonano analizy przekrojowe przy wykorzystaniu określonych wskaźników. Dodatkowo autorzy porównali osiągnięcia tych czterech państw. Rygorystyczne reguły fiskalne UE były po cichu omijane, ale częściej przez państwa członkowskie niż państwa kandydujące. Stwierdzenie to opierało się na argumentach prawnych i ekonomicznych oraz oszacowaniach matematycznych. W związku z tym autorzy postawili pytania o polityczną odwagę i zdolność finansową badanych państw do radzenia sobie z paktem fiskalnym, jaki obowiązuje 28 państw członkowskich UE. Odpowiedzi na te pytania zostały poparte licznymi analizami, 
zawartymi w raportach UE dla poszczególnych państw, a także tabelami i danymi liczbowymi, które umożliwiają porównanie wyników państw i ich osiągnięć gospodarczych z wymogami UE dotyczącymi konsolidacji fiskalnej. Dodatkowo, jako punkt odniesienia, wykorzystano średnią dla UE-28. W konkluzji przedstawiono wyniki analizy krzyżowej między tymi czterema państwami a 28 państwami członkowskimi UE, wraz z towarzyszącą im argumentacją dotyczącą głównego stwierdzenia o postępach badanych państw bałkańskich w obszarze prawa i gospodarki, a także prognozą na przyszłość.

Słowa kluczowe: pakt fiskalny UE, konsolidacja fiskalna, deficyt budżetowy, dług publiczny, bałkańskie państwa kandydujące 